\title{
Penyuluhan Pengembangan Manajemen Sumber Daya Manusia Karang Taruna Cidokom Gunung Sindur Bogor Jawa Barat
}

\author{
Udin $_{\text {Ahadin }}{ }^{*}$, Yanuarianto ${ }^{2}$, Triyadi ${ }^{3}$, Retno Japanis Permatasari ${ }^{4}$, \\ Theobaldus Boro Turo 5 \\ 1,2,3,4,5 Program Studi Manajemen, Fakultas Ekonomi, Universitas Pamulang \\ Jl. Surya Kencana No.1, Pamulang Barat, Kec. Pamulang \\ Kota Tangerang Selatan, Banten 15417 \\ *Penulis Korespodensi: dosen00406@unpam.ac.id \\ DOI : $10.32672 / \mathrm{btm} . v 1 \mathrm{i} 4.1722$
}

\begin{abstract}
The purpose of this community service activity is to fulfill the obligations of lecturers to carry out tridharma of higher education. For that reason, it has become an obligation for lecturers to share their knowledge and insights through counseling the development of human resource management so that they will always strive to achieve organizational goals effectively and efficiently. And also aims at Cidokom Youth Organization can perform its functions and roles optimally so that it brings benefits to Cidokom Village, Gunung Sindur District, Bogor. The development is also intended to improve the quality of human resources in carrying out their duties so that it is more positive in contributing energy and thoughts to advance Cidokom Village, Gunung Sindur Sub-District, Bogor Regency, West Java. Dedication method with counseling, discussion and question and answer as well as personal evaluation.After the counseling activities on human resource management are carried out, youth or youth can implement the Karang Taruna activities so that the purpose of the Karang Taruna Youth Organization to help and advance the local community can be realized. Keywords: Human Resource Management
\end{abstract}

\begin{abstract}
ABSTRAK
Tujuan dari kegiatan pengabdian kepada masyarakat ini adalah untuk memenuhi kewajiban dosen untuk melakukan tridharma perguruan tinggi. Untuk itu sudah menjadi kewajiban bagi dosen berbagi pengetahuan dan wawasan melalui penyuluhan pengembangan manajemen sumber daya manusia agar senantiasa berupaya mencapai tujuan organisasi dengan efektif dan efisien. Dan juga bertujuan Karang Taruna Cidokom dapat menjalankan fungsi dan perannya secara optimal sehingga mendatangkan manfaat bagi Desa Cidokom Kecamatan Gunung Sindur Bogor. Pengembangan juga dimaksudkan untuk meningkatkan kualitas sumber daya manusia dalam melaksanakan tugasnya sehingga lebih positif dalam berkontribusi tenaga dan pikiran untuk memajukan Desa Cidokom Kecamat Gunung Sindur Kabupaten Bogor Jawa Barat. Metode pengabdian dengan penyuluhan, diskusi dan tanya jawab serta evaluasi secara personal. Setelah kegiatan penyuluhan mengenai manajemen sumber daya manusia
\end{abstract}


Udin Ahadin, dkk.

dilaksanakan, para remaja atau pemuda dapat mengimplementasikan pada kegiatan Karang Taruna sehingga tujuan dari Karang Taruna Cidokom untuk membantu dan memajukan masyarakat setempat dapat diwujudkan.

\section{Kata Kunci: Manajemen Sumber Daya Manusia}

\section{PENDAHULUAN}

Manajemen sumber daya manusia diartikan sebagai ilmu yang mengatur manusia dalam suatu organisasi sebagai pondasi untuk mencapai tujuan. Tujuan utama manajemen sumber daya manusia yaitu untuk memaksimalkan sumber daya ekonomi yang memiliki rasa dan karsa untuk menjalankan suatu organisasi. Dewasa ini sumber daya manusia bukan semata-mata sumber daya ekonomi, tetapi merupakan aset bagi organisasi, atau diistilahkan human capital. Artinya, aset bernilai yang dapat dikembangkan sebagai investasi bagi organisasi. Manajemen sumber daya manusia sangat penting mengingat dengan perkembangan teknologi dan informasi saat ini cenderung mengkondisikan dalam menjalankan organisasi berdasarkan sistem atau lebih dikenal dengan Management by system. Keberadaan sumber daya manusia seakan ke geser tergantikan sistem, maka dari itu sebagai penggerak, dan pondasi dalam menjalankan organisasi posisi sumber daya manusia tidak boleh kalah dengan sistem. Sumber daya manusia harusnya yang menciptakan sistem untuk membantu memudahkan dan meringankan pekerjaan manusia bukan dikendalikan oleh sistem. Pada hakikatnya sumber daya manusia merupakan penggerak, pemikir, dan perencana untuk mencapai tujuan organisasi..

Permasalahnya, seiring dengan perkembangan teknologi yang seharusnya diimbangi dengan berkembangnya kualitas sumber daya manusia, pada riilnya masih banyak yang belum mampu beradaptasi dengan perkembangan teknologi tersebut, sehingga banyak organisasi yang kalah saing karena sumber daya manusia nya masih belum cukup kompeten. Seperti halnya organisasi social dalam masyarakat seperti Karang Taruna merupakan wadah membentuk dan membangun sumber daya manusia yang kompeten melalui organisasi masyarakat. Karang Taruna Cidokom yang berlokasi di Desa Cidokom Kecamatan Gunung Sindur Kabupaten Bogor merupakan salah satu karang taruna di berbagai wilayah, yang merupakan wadah menumbuhkan dan mengembangkan kualitas sumber daya manusia. Karang Taruna merupakan organisasi social yang beranggotakan para remaja, disini remaja dapat mengembangkan diri sesuai potensi masing-masing. Dan merupakan organisasi social dalam masyarakat sehingga perannya memang membantu masyarakat setempat. Untuk itu perlu pembinaan berkelanjutan agar para remaja tumbuh berkembang menjadi manusia dewasa yang berkualifikasi.

\section{METODE PELAKSANAAN KEGIATAN}

\section{Tahap Pemilihan Lokasi Pengabdian}

Tahap pemilihan lokasi pengabdian kepada masyarakat tentu harus mempertimbangkan banyak hal., salah satunya adalah kebutuhan masyarakat yang merupakan objek dari pengabdian. Karang Taruna Cidokom Kecamatan Kecamatan 
BAKTIMAS

Jurnal Pengabdian pada Masyarakat
Vol. 1, No. 4,

Desember 2019
eISSN 2685-113x

pISSN 2685-0303

Gunung Sindur Kabupaten Bogor menjadi lokasi pilihan karena melihat karang taruna ini aktif dan antusias untuk mengembangkan organisasinya dan memajukan Desa Cidokom . Respon ketua dan jajaran pengurusnya untuk menerima masukan, atau wawasan baru sangat welcome, artinya responnya sangat positis saat tim pengusul berkunjung dan bersilaturrohim serta menyampaikan tujuan kedatangan tim pengusul. Artinya, Karang Taruna Cidokom Kecamatan Gunung Sindur dapat bersinergi dengan civitas akademika untuk bersama-sama membangun masyarakat baik dari bidang pendidikan, seni, budaya, social maupun sumber daya manusia..

\section{Tahap Pengusulan}

Setelah tim pengusul melakukan observasi awal dan sudah mengidentifikasi permasalahan pada objek pengabdian kepada masyarakat, maka dapat ditentukan temanya atau judulnya. Selanjutnya berdasarkan tema tersebut disusunlah proposal pengabdian kepada masyarakat yang diajukan melalui program Sintias.

\section{Tahap Pengumpulan data}

Pengumpulan data yaitu mengumpulkan data di lokasi pengabdian dengan melakukan konsultasi, observasi, wawancara, dan dokumentasi dengan menentukan strategi pengumpulan data yang dipandang tepat untuk menentukan tema atau fokus serta pendalaman data pada proses pengumpulan data berikutnya. Pada tahap pengumpulan data ini ditujukan untuk mengidentifikasi permasalahan yang dihadapi atau tema yang dibutuhkan oleh warga / masyarakat.

\section{Tahap Persiapan Pelaksanaan}

Tahap persiapan ini, dilakukan koordinasi secara intensif dengan anggota (tim) agar pelaksanaan kegiatan pengabdian kepada masyarakat dapat berjalan lancar. Persiapan materi penyuluhan, menyiapkan pemateri/narasumber, persiapan konsumsi, daftar hadir dan perlengkapan lain yang dibutuhkan terkait pelaksanaan kegiatan.

\section{Tahap Pelaksanaan Pengabdian Kepada Masyarakat}

Tahap pelaksanaan pengabdian kepada masyarakat merupakan tahap pelaksanaan penyuluhan tentang manajemen sumber daya manusia untuk pengembangan Karang Taruna Cidokom Kecamatan Gunung Sindur Bogor. Pada. tahap ini tim pengusul melakukan penyuluhan sesuai tema terkait, melakukan sharing pendapat, dan mengidentifikasi kebutuhan materi yang diinginkan dan penawaran program pengabdian kepada masyarakat berkelanjutan di masa-masa yang akan datang. Langkah ini dilakukan tim pengusul agar program pengabdian kepada masyarakat ini berjalan lancar dan tepat sasaran sesuai dengan tujuan dilakukannya pengabdian kepada masyarakat.

\section{Tahap Pelaporan Hasil Pengabdian}

Pada tahan pelaporan hasil pengabdian kepada masyarakat ini merupakan laporan serangkaian kegiatan mulai dari surve pra pengabdian hingga pelaporan kegiatan. Hasil yang diperoleh tim pengusul diinterpretasikan agar dapat bermanfaat pagi pembaca ataupun pengguna, selain itu juga dapat referensi pengabdian berikutnya. Tentu akan dilampirkan bukti pendampingan pemetaan segmentasi pasar dan strategi 
Udin Ahadin, dkk.

pemasaran dan data hasil penjualan hasil kreatifitas bambu ini setelah ada pendampingan

\section{Tahap Publikasi}

Hasil atau laporan kegiatan pengabdian kepada masyarakat dipublikasikan sebagai luaran dari kegiatan pengabdian kepada masyarakat ini agar dimanfaatkan sebagai referensi bagi penelitian atau kegiatan pengabdian kepada masyarakat di masa yang akan datang.

\section{HASIL DAN PEMBAHASAN}

Secara umum karang taruna merupakan suatu organisasi kepemudaan di Indonesia sebagai wadah pengembangan jiwa sosial generasi muda. Karang taruna tumbuh atas kesadaran dan rasa tanggung jawab sosial dari masyarakat dan untuk masyarakat itu sendiri khususnya generasi muda yang ada di suatu wilayah desa, kelurahan atau komunitas yang sederajat, terutama bergerak pada bidang-bidang kesejahteraan sosial. Seperti bidang ekonomi, olahraga, keterampilan, keagamaan dan kesenian sesuai dengan tujuan didirikannya karang taruna untuk memberikan pembinaan dan pemberdayaan kepada para remaja di suatu desa atau wilayah itu sendiri. Sebagai organisasi sosial kepemudaan karang taruna merupakan wadah atau tempat pembinaan dan pengembangan dalam upaya mengembangkan kegiatan ekonomi, sosial, budaya dengan memanfaatankan semua potensi yang ada di lingkungan masyarakat, baik sumber daya manusia maupun sumber daya alam yang telah tersedia.

Manajemen sumber daya manusia merupakan salah satu matakuliah yang disajikan diperguruan tinggi program studi Manajemen ataupun Akuntansi, Ditingkat sekolah menengah Manajemen sumber daya manusia tidak semata-mata disajikan dalam kurikulum tetapi bisa disisipkan pada mata pelajaran IPS. Sebenarnya pendidikan yang paling efektif dan efisien adalah pendidikan yang dimulai dari pendidikan keluarga, selain lingkungan pertama kali yang dikenal anak adalah lingkungan keluarga, waktu yang paling banyak juga dihabiskan di keluarga, sehingga karakter yang terbentuk lebih dominan dari pendidikan keluarga. Manajemen sumber daya manusia di lingkungan keluarga dapat dimulai dengan anak diberikan pendidikan diberi kesempatan untuk bersosialisasi, mengerjakan tugas secara berkelompok atau diberi tanggung jawab sesuai dengan tingkatan usianya. Perlu dibiasakan dari lingkungan keluarga agar anak tumbuh menjadi pribadi yang berkarakter dan berkualitas. Dengan memberikan kesempatan pada anak untuk memanajemen atau mengelola diri sendiri, anak secara otomatis akan merasa diberi kepercayaan dan tanggung jawab pada diri anak. Anak akan dapat mengambil keputusan yang baik untuk dirinya sendiri, meskipun tetap dalam pengawasan orang tua. Begitu anak tumbuh remaja sudah mempunyai dasar sebagai sumber daya manusia yang berintegritas. Kebiasaan yang positif harus terus dilakukan dan dikembangkan pada diri anak, sehingga tumbuh kembang mereka terarah menjadi bibit-bibit sumber daya manusia yang berkualitas. 
BAKTIMAS

Jurnal Pengabdian pada Masyarakat
Vol. 1, No. 4,

Desember 2019
eISSN 2685-113x

pISSN 2685-0303

Pentingnya manajemen sumber daya manusia dalam kehidupan sehari-hari menjadi tolak ukur perilakunya dalam bermasyarakat. Kebiasaan di lingkungan keluarga juga dapat dicerminkan dalam Interaksinya dengan sesama manusia di lingkungan social. Oleh sebab itu kebiasaan yang baik dapat ditumbuh kembangkan pada lingkungan yang lebih luas dalam hal ini di organisasi social masyarakat seperti halnya karang taruna. Karang taruna yang merupakan wadah remaja dan dewasa untuk mengembangkan kreativitas dan produktivitas. Mulai dari kalangan remajanya perlu ditumbuhkan bagaimana membangun sumber daya manusia yang tangguh dan tanggung jawab. Pendidikan keluarga yang merupakan pendidikan pertama bagi tumbuh kembangnya anak, perlu membiasakan mendidik putra putrinya mengelola dirinya dengan baik, dan cara diberi kesempatan untuk mandiri, disiplin, tanggung jawab dan berani mengambil resiko.

Untuk itu tim pengusul pengabdian kepada masyarakat dari dosen dan mahasiswa Universitas Pamulang hadir ditengah-tengah masyarakat untuk berbagi pengetahuan tentang manajemen sumber daya manusia agar masyarakat memiliki nilai lebih, karena manusia memang terlahir lebih bermartabat dibanding makhluk lain, sudah seyogyanya manusia harus lebih unggul dan bermartabat. Akal dan pikiran yang dianugerah sejak dilahirkan digunakan sebagai modal dasar mengembangkan diri sebagai manusia. Meskipun para remaja sudah mendapat wadah dan tergabung dalam organisasi social yaitu karang taruna bukan berarti terlepas tanggung jawab kita untuk memberikan perhatian, dukungan, motivasi, keterampilan dan pengetahuan. Justru pada usia remaja yang masih tergolong labil harus ditanamkan nilai-nilai kepribadian yang baik, agar tumbuh menjadi insan yang baik juga. Dari surve awal tim pengusul melihat gejala krisis moral yang melanda masyarakat Indonesia, terutama di kota-kota besar. Arus globalisasi tidak bisa dicegah, mau tidak mau, suka tidak suka sudah terjadi, jadi tinggal bagaimana kita menyikapi arus globalisasi tersebut. Arus globalisasi akan menjadi kekuatan yang luar biasa jika dimanfaatkan dengan baik dan benar, tetapi sebaliknya akan menjadi mala petaka jika tidak dimanfaatkan dengan baik. Maka dari itu sudah menjadi kewajiban kita untuk mengkondisikan remaja kita dalam kegiatan yang positif dan bermanfaat.

Untuk itu solusi yang dapat ditawarkan dengan memberikan penyuluhan tentang pengembangan manajemen sumber daya manusia karang taruna yang merupakan wadah bagi para remaja. Pengabdian kepada masyarakat pengembangan manajemen sumber daya manusia diberikan dalam kemasan penyuluhan agar lebih mudah dipahami. Dengan pendekatan persuasif diharapkan para remaja lebih terbuka untuk ,menyampaikan permasalahan yang dihadapi atau menyampaikan kebutuhan mereka terkait dengan pengembangan diri. Pemilihan lokasi pengabdian kepada masyarakat dengan melakukan penyuluhan kepada anggota Karang Taruna Cidokom Kecamatan Gunung Sindur Bogor yang beranggotakan 28 orang dari berbagai latar belakang social dan berbagai jenjang pendidikan. Dengan penyuluhan tentang manajemen sumber daya manusia di kalangan Karang Taruna Cidokom Kecamat Gunung Sindur Kabupaten Bogor Jawa Barat diharapkan dapat memberikan wawasan kepada anggota yang nantinya dapat diimplementasikan oleh anggota dan ditularkan ke masyarakat luas.

Solusi dengan memberikan penyuluhan tentang pengembangan manajemen sumber daya manusia Karang Taruna Cidokom Kecamatan Gunung Sindur ini 
Udin Ahadin, dkk.

sebenarnya juga masih belum cukup untuk meningkatkan kualitas sumber daya manusia, masih banyak hal yang dapat dilakukan dengan memberikan ketrampilan dan kesempatan untuk pengembangan diri. Secara berkelanjutan tim pengusul akan terus melakukan binaan untuk berbagi pengetahuan dan pengalaman dalam kemasan pengabdian kepada masyarakat. Tim pengusul pengabdian kepada masyarakat akan terus berupaya meningkatkan produktivitas masyarakat dengan menyesuaikan potensi masyarakat setempat. Pengambangan manajemen sumber daya manusia disajikan lebih dulu dengan pertimbangan pengetahuan ini merupakan dasar untuk dapat meningkatkan kualitas diri sebagai bekal untuk mencapai tujuan hidup. Seseorang yang sudah matang pola pikir atau memiliki kemampuan menyikapi hidup secara efektif dan efisian cenderung lebih memiliki daya tahan untuk menghadapi segala permasalahan.

Permasalahan yang ada di masyarakat sangat komplek dan variatif, serta tidak sesederhana yang bisa ditangkap oleh mata. Untuk mengetahui permasalahan yang ada dalam masyarakat tentu perlu pendekatan pada masyarakat setempat baru dapat memberikan jalan keluar sebatas yang mampu dilakukan untuk membantu memberikan solusi. Begitu juga dengan Karang Taruna Cidokom Kecamatan Gunung Sindur untuk mengembangkan organisasinya tentu tidak hanya butuh pengetahuan tentang manajemen sumber daya manusia tetapi juga pengembangan ketrampilan untuk meningkatkan produktifitas sehingga melalui wadah tersebut dapat dikembangkan lagi untuk meningkatkan potensi. Dalam kesempatan melakukan kegiatan pengabdian kepada masyarakat tim pengusul akan terus berusaha membantu meningkatkat kualitas sumber daya manusia pada masyarakat setempat.

\section{Simpulan}

\section{PENUTUP}

Hasil kegiatan ini di harapkan para remaja tergerak untuk ikut membangun desa sebagai generasi penerus bangsa tersebut melalui kemasan kegiatan penyuluhan "manajemen sumber daya manusia untuk pengembangan Karang Taruna Cidokom Kecamatan Gunung Sindur Kabupaten Bogor, dengan tujuan dapat mengembangkan peran karang taruna sebagaimana fungsinya. Obyek pada kegiatan pengabdian kepada masyarakat ini adalah Karang Taruna yang anggotanya terdiri dari para remaja di wilayah Desa Cidokom Kecamat Gunung Sindur Kabupaten Bogor Jawa Barat karena tim pengusul melihat Karang Taruna Cidokom masih butuh pembinaan dalam mengelola sumber daya manusia nya agar lebih greget dan sungguh-sungguh, penuh tanggung jawab dalam menjalankan fungsi dan perannya pada masyarakat setempat, sehingga dapat memajukan Desa Cidokom.

Setelah kegiatan penyuluhan mengenai manajemen sumber daya manusia dilaksanakan, para remaja atau pemuda dapat mengimplementasikan pada kegiatan Karang Taruna sehingga tujuan dari Karang Taruna Cidokom untuk membantu dan memajukan masyarakat setempat dapat diwujudkan 
BAKTIMAS

Jurnal Pengabdian pada Masyarakat
Vol. 1, No. 4,

Desember 2019
eISSN 2685-113x

pISSN 2685-0303

\section{DAFTAR PUSTAKA}

Handoko, Hani. (2012). Manajemen Personalia dan Sumber Daya Manusia Edisi 2. BPFE Yogyakarta.

Lucia, Putri, Iqbal. (2019). Pengembangan Sumber Daya Manusia di Yayasan Pembangunan Masyarakat Sejahtera Kelurahan Kedaung Pamulang Tangerang Selatan. Jurnal Pengabdian DHARMA LAKSANA. Volume 1 Nomor 2 Januari.

Sunarsi, D. (2018). Analisis Motivasi Kerja Tenaga Pendidik Sukarela Pada Pusat Kegiatan Belajar Masyarakat (PKBM) Bimasda Kota Tangerang Selatan. Kreatif: Jurnal Ilmiah Prodi Manajemen Universitas Pamulang, 6(2), 53-65.

Sutrisno, (2014). Manajemen Sumber Daya Manusia. Kencana Predana Media Group. Jakarta 